Research, part of a Special Feature on Global Water Governance: Challenges and Future Scope

\title{
Thinking about the Future of Global Water Governance
}

\author{
$\underline{\text { Joseph W. Dellapenna }}{ }^{1}, \underline{\text { Joyeeta Gupta }}^{2}$, Wenjing Li $^{3}{ }^{\text {and Falk Schmidt }}{ }^{4}$
}

ABSTRACT. Global water problems are likely to increase in severity, rendering existing governance approaches unable to cope with the resulting problems. We inquire into the relationship between global water governance structures, particularly those involving the United Nations, and look at how those structures are likely to respond to and shape projected water futures. Building on story lines of possible water futures taken from existing scenarios, we discuss the functions to be performed by global water governance. We aim to open a discussion about four global water governance options and to introduce the constraints and possibilities for each option. We argue that the nature of the water problem calls for structural changes. However unfeasible these may appear today, such transitions do occur, and, if the narrative is sufficiently sound, it can be used by social movements and networks to mobilize policy entrepreneurs and directional leaders to work for such changes.

Key Words: framework treaties; global organization; markets; regulatory options; water governance

\section{INTRODUCTION}

Existing water governance is poorly equipped to cope with the increasing pressure on water resources. This is particularly true for the global dimension of water governance. For national responses see Burchi (2012). Despite good reasons against considering the global dimension of water governance as the major point of intervention (see, e.g., Conca 2006), some argue that the water crisis must be addressed as a global crisis involving a global water system (Hoekstra 2006, Hoff 2009, Rockström et al. 2009). A multilevel approach captures the governance challenge for water and includes the global dimension (Pahl-Wostl et al. 2008), and avoids getting stuck in a debate about the right point of intervention (Gupta 2008). However, not much has been written about how to engage the global dimension.

Global water governance is neither fully absent nor fully ineffective, yet much remains to be done if it is to cope with the increasing pressures on the world's water resources. Water has been on the agenda of many summits, from the Stockholm Conference on the Human Environment in 1972 to the June 2012 Rio+ 20 Earth Summit, yet water governance is only loosely institutionalized on the global level. Recommendations produced at United Nations (UN) gatherings arguably are more legitimate and have greater steering power than those produced at non-UN forums such as the World Water Forum (WWF) meetings (Gleick and Lane 2005). Even so, UN multilateralism faces many challenges (Gupta 2006, Newman et al. 2006). Some UN meetings, although full of good intent, produce only overarching norms and weak legal rules and procedures, or provide few resources to implement the recommendations. At the Rio+20 Summit in June 2012, parties agreed on the need to integrate water in sustainable development and advised countries to adopt measures supported by "international assistance and cooperation"
(UNCSD 2012). This scarcely presents a governance design capable of dealing with the projected increases in water problems. To promote any institutional reform, we need to explore which form should follow which function (Biermann and Bauer 2005, Young 2008).

We inquire into the relation between global water governance structures and the possible outcomes in terms of addressing impending water crises. We discuss global water governance problems and outline key governance options, with a focus on UN bodies. To do so, we present scenarios of possible directions of global changes and some suggestions of how they may impact on water and water governance over the coming 40 years. We identify challenges that could be suitably addressed at the global level and the possible institutional and legal responses to these challenges. We compare possible responses with a view to their compatibility with one or another of the possible futures. We close by considering how a preferred strategy might facilitate getting to a possible future.

\section{STORIES OF POSSIBLE WATER FUTURES}

No one can predict the planet's water future with certainty. Although climate disruption is occurring, the intensity and location of effects remain uncertain (IPCC 2007). One approach that helps to decide how to act under uncertainty is to apply insights generated by certain general scenarios. Scenarios are "plausible descriptions, without ascribed likelihoods, of possible future states of the world" (IPCC 2007:32). To prepare for these uncertainties, the Millennium Ecosystem Assessment (MEA 2005), the Intergovernmental Panel on Climate Change (IPCC 2007, 2010), and the Global Environmental Outlook-4 (GEO-4; UNEP 2007) have developed scenarios. Kämäri et al. (2008) have developed future European water scenarios, and new global water scenarios are being developed (Hayward 2012).

\footnotetext{
${ }^{1}$ Villanova University School of Law, Villanova, Pennsylvania, USA, ${ }^{2}$ University of Amsterdam, Netherlands, ${ }^{3}$ Attorney, Beijing, ${ }^{4}$ Institute for Advanced Sustainability Studies, Potsdam, Germany
} 
These scenarios describe, among other things, different conditions for future water worlds, including increases in water demand and the impacts of climate change (Kämäri et al. 2008, UNESCO 2009). These scenarios analyze human impacts on the planetary life support systems. Social sciences have been engaging with scenarios for some time (Pulver and VanDeveer 2009), using them to highlight potential future challenges and to provide a useful starting point for analysis of reforms of existing global governance institutions.

\section{Story lines in environmental scenarios}

Pahl-Wostl et al. (2008) concluded by discussing these story lines, and we build on these further in this paper. Briefly recapitulating, the IPCC (2007) has four scenarios:

- A1, rapid economic growth, technology development, population peaking in the middle of the century, high cultural and social interaction;

- A2, a heterogeneous world in which countries and people focus on self-reliance and local identities;

- B1, global population peaks midcentury, regions converge toward an environmentally sustainable and equitable service and information society;

- B2, decentralized, sustainable and equitable societies

Millennium Ecosystem Assessment scenarios (MEA 2005) include:

- Global orchestration: sustainable development, fair trade, and global education;

- Techno garden: green technology, tradeable rights, and technical expertise;

- Order from strength: environmental conservation and greater regionalization;

- Adapting mosaic: decentralized management.

GEO-4 (UNEP 2007) has the following scenarios:

- Policy first: top-down governance with active stakeholder inputs;

- Sustainability first: cogovernance in promoting environmental sustainability and equity;

- Security first: powerful actors have security goals;

- Markets first: decentralized market mechanisms.

Each scenario features a need to respond to growing water crises that come about both from rising demand and from climate-driven changes in water availability (UNESCO 2006, IPCC 2007, UNEP 2007, Vörösmarty et al. 2010). For example, regional climate changes affect many physical and biological systems, which in turn affect human systems (IPCC 2007), particularly water resource systems (IPCC 2007, UNEP 2007). Changes in farming techniques and urban and industrial growth often result in demand that exceeds the available freshwater (UNEP 2007). Climate disruption, largely through its impact on the oceans, will affect rainfall patterns, which will compound the effects of human activity (IPCC 2007, UNEP 2007). Arid regions will become wider and drier, and water management infrastructure may become effectively obsolete (IPCC 2007). The MEA and the GEO-4 scenarios also reflect key governance patterns and provide some guidance on how to design governance options (see Fig. 1).

Fig. 1. Regulatory governance options linked with scenarios

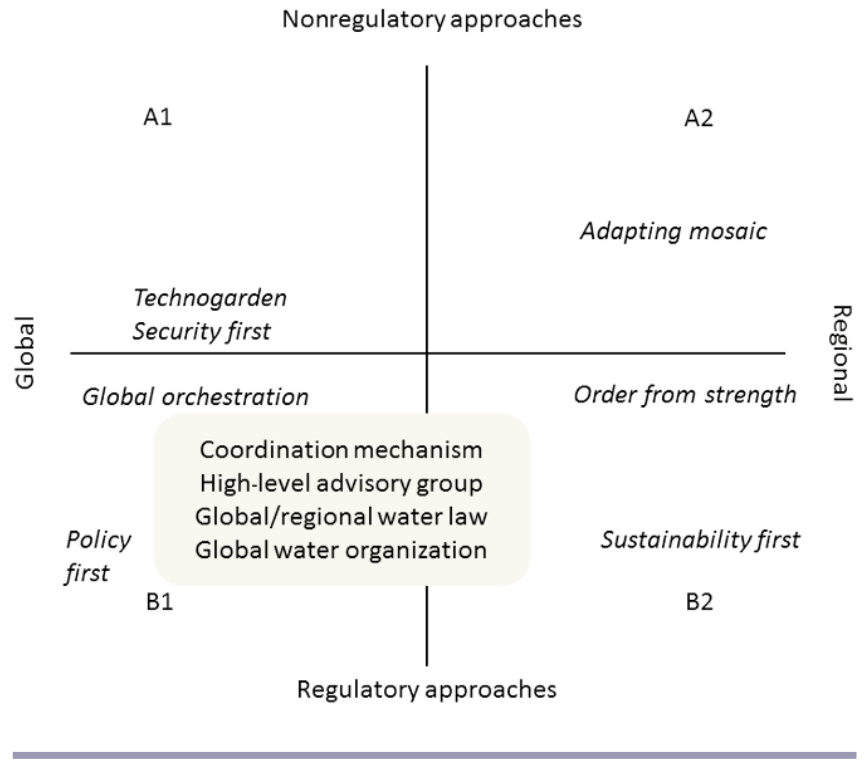

\section{Governance options}

Governance options exist on a continuum that ranges from governmental to nongovernmental, from regulatory to nonregulatory, from formal to informal, and from the local level to the global level. These options are not mutually exclusive and could be experimented with simultaneously.

The scenarios reveal that there may be a critical role for global cooperation and/or regional intergovernmental cooperation and that if governing agencies fail to fulfill their goals, market forces may become more important. Some scenarios directly favor the market option for water management (Griffin 2006, Hoekstra 2006). After all, when people, even poor people, can see a real benefit from something, they are willing to pay for it if they can. Consider, for example, how readily cell phones have spread, even into the poorest communities. The question is, however, whether water resources or other environmental public goods are suitable for market solutions (Rothfeder 2001, Barlow and Clarke 2002, Dellapenna 2008). Furthermore, markets can lead to private confidential contracts not subject to public scrutiny that are often subject to secret arbitration proceedings under international investment law 
when the contract fails, which puts developing countries at risk in international litigation (Tecco 2008, Klijn et al. 2009).

Markets are unable to manage environmental public goods in the developed countries because markets, built on systems of private property, cannot deal adequately with the public dimensions of shared goods such as a river or an aquifer (Breitmeyer et al. 2006, Dellapenna 2008). Markets can solve some water management problems on a small scale, e.g., transfers among similar users over short distances or the distribution of small quantities of water in closed containers, and in specific contexts, but they will be of limited utility on a global scale. Although market forces have a part to play, they are inadequate, on their own, to govern global water and hence there are reasons to investigate the possible scenarios for improving regulatory governance options.

There is debate about which governance options are superior and whether multilevel is better than bottom-up or top-down governance (Pahl-Wostl et al. 2008). Water governance research has focused mostly on the local through the national to transboundary levels (Dellapenna 1994). These levels have to be complemented by including the global dimension. In 2001, the IPCC listed factors that must be considered for an effective response to the coming challenges (IPCC 2001; see also Solanes and Jouravlev 2006, UNEP 2007): The institutional capacity to adapt to changes; the effectiveness of legal frameworks for water administration; the sufficiency of resources to handle the various water challenges, including natural, human, or economic resources; the state of technology; the mobility of human populations; the ability to address the speed and potentially nonlinear nature of future disruptions; the ability to cope with the complexity of water governance, e.g., stemming from the cross-sectoral nature of the water resources; and the ability to assess current and projected water related challenges.

In addition, Young's (2008) "diagnostic method" suggests that we consider the nature of the problem, the players, the practices and the politics as criteria for diagnosis (Young 2008, 2010). For example, global water governance addresses a multilevel problem; has to reconcile different players, e.g., state and nonstate; has to move from providing "soft functions" such as information sharing to "hard functions" such as "regulation;" and has to deal with win-lose situations (upstreamdownstream or otherwise), as well as with soft issues such as fairness and the power of ideas, such as a human right to water, at the same time.

We merge the above criteria to examine whether there is a fit between the governance option and the nature of the problem, whether the actors and bodies have the institutional capacity/ legal mandates/resources to deal with a nonlinear problem; and whether they can respond in an agile and adaptive manner.

\section{KEY GOVERNANCE OPTIONS IN RELATION TO THE SCENARIOS}

Global water governance today aims at "water for all" set forth in the Millennium Development Goals (UN 2000), supplemented by the growing recognition of a human right to water and sanitation (UN 2010) and by less clear-cut and less institutionalized "sustainable water resource management" (Loucks 2000). Today, numerous transnational or international institutions for water governance affect governance at the global or regional levels (Dellapenna and Gupta 2008, Pahl-Wostl et al. 2008). These include formal institutions created under UN auspices or other international organizations, or by multilateral or bilateral treaties (Dellapenna 1994, UNEP 2007). They also include informal institutions created by water-oriented professional associations, i.e., so-called epistemic communities, civil society groups, or marketplace participants.

Although mainstream perspectives on governance often focus on government's regulatory power, institutional analysis demonstrates that various functions are deliverable by different institutional arrangements and that specific problems may require specific functions (Young 2010). Existing global institutions addressing water are very weak in terms of regulation, but they are relatively good at agenda setting, sharing information, mobilizing people, and, to a certain degree, in mobilizing resources (Schubert 2010, Schubert and Gupta 2013). Even if such soft governance functions, which are characteristic for many parts of the UN system, may be insufficient to address the challenges introduced above, it would be inappropriate to neglect these functions.

If we examine the impacts of possible scenarios on water, we find that existing global water governance arrangements are not up to the task. If, for example, increasing demand for water for food production requires a global regulatory regime to allocate water at a global level efficiently, including a managed virtual water trade (Hoekstra 2006), much harder functions must be delivered than the current soft steering of the global water governance system. However, many observers will object to this conclusion. Some will point to the Inspection Panel of the World Bank (created in 1994) as an example of an existing institution that ensures the Bank's accountability to civil society for project development and management. The panel was created in response to the Narmada Dam problems in India and has since dealt with water projects such as the Arun Valley case in Nepal. Notwithstanding its work, the World Bank continues to receive harsh criticism for the environmental and social effects of its water projects (van Putten 2008).

\section{A high-level advisory group}

The easiest governance option to implement is a high-level advisory group. Such a group would bring water governance functionaries together periodically to exchange information 
about water, water uses, and managerial practices at the global to transboundary level. Examples include the UN SecretaryGeneral's Advisory Board on Water and Sanitation (SGAB, created in 2004) and hybrid bodies such as the Global Water Partnership (GWP), founded in 1996 by the World Bank, the UN Development Programme, and the Swedish International Development Cooperation Agency (Rana and Kelly 2004). Such approaches open doors without threatening anyone directly, because the group has no formal authority and no money to dispense. The SGAB, for example, meets twice a year, with board members serving without pay but receiving reimbursement for travel and lodging. It needs money for publishing and to maintain a secretariat of three persons. Such advisory groups provide certain functions better than others. For example, they are good at agenda setting. Thus the SGAB created the Hashimoto Action Plan (UNSGAB 2006, 2010), which includes actions necessary to finance, develop, and implement integrated water resources management. The SGAB also promoted adoption of a human right to water and sanitation, approved by the General Assembly in 2010. The GWP similarly helps national and subnational water governance institutions finance, develop, and implement integrated water resource management (Rana and Kelly 2004). However, these agendas do not carry a binding commitment and provide no direct financial support for their implementation. Their impacts may be limited to the advocacy of principles and norms. Such groups are often seen by nongovernmental organizations as being undemocratic and promoting inappropriate panaceas that are not based on a legitimate consensus process. Their very shortcomings, however, make them politically relatively easy to achieve.

The IPCC criteria for evaluating the likely effectiveness of a high-level advisory group demonstrates that such an approach is not likely to be adequate (IPCC 2001). Although a highlevel advisory group is likely to be able to adapt to change rapidly and can comprehend and cope with the often nonlinear nature of changes in water availability, use, and management, it would not provide a legal framework and it would lack the resources to respond effectively to any of the challenges that are already emerging. In short, a high-level advisory group will be unable to cope with the complexity of water governance, and the institutional fit with the problem is likely to be weak.

\section{A coordination agency}

A stronger option would be an institution for active coordination of the activities of operational institutions. The United Nations established UN-Water in 2003 after the Johannesburg Summit of 2002 for this purpose. It includes 30 $\mathrm{UN}$ agencies dealing with water as well as some 24 non-UN institutions, including the GWP and WWF. It creates special task forces, now called thematic priority areas, to address particular concerns such as transboundary waters or sanitation; supports regional initiatives; and runs three programs, including the World Water Assessment Programme, which prepares the World Water Development Report triennially.

Like the high-level advisory groups, UN-Water is not intended to make firm decisions that strongly impact the water agenda of its individual members. UN-Water is perhaps more than the sum of its individual members and, in fact, is often said to represent a significant improvement over the UN Administrative Committee on Coordination Subcommittee on Water Resources, its predecessor. Under its current "light" set-up, however, it will be unlikely to transform the water policies of its individual members to have an overarching global water agenda (Baumgartner 2010, UN-Water 2010, Schubert and Gupta 2013). UN-Water operates in the background and influences the procedures of global water governance, rather than the substance (Baumgartner and PahlWostl 2013). The global dimension of multilevel water governance may need a stronger and more coherent voice, both building upon and transcending its individual members, if necessary.

It is questionable whether such an agency can cope with projected increased water stress as put forward by the different scenarios or as already manifested in observed changes. One possible response would be to create or strengthen the regulatory function of this institutional arrangement, perhaps through a strong reading of the term "coordination" in the UNWater mandate. Some might question whether the problems are just too big and varied for a single small coordinating agency to manage effectively. The problem of climate change is global and justifies stronger global coordination (Young 2008). Sanitation, on the other hand, a cumulative global crisis, requires global awareness raising and resource mobilization, but mostly implementation at ground level. Applying the IPCC criteria, we conclude that although a coordinating agency is likely to be able to adapt to change rapidly and can comprehend and cope with the often nonlinear nature of changes in water availability, use, and management, it provides a limited legal framework and lacks the authority, mandate, and resources to institutionalize and implement the necessary policies.

\section{A framework water treaty}

There are hundreds of framework water treaties or directives, ranging from bilateral to global (Dellapenna 1994). A framework treaty provides principles around which interested nations can craft a specific legal regime to govern and constrain water management systems. More than 30 years of global water governance has created all the ingredients for a global framework treaty that goes beyond simply resolving transboundary disputes: principles, norms, rules, decisionmaking procedures, and programs. There are three possible options. First, existing treaties can be strengthened individually or rearranged to constitute a more coherent and stronger overarching global water treaty. The UN Convention on the Law of Non-Navigational Uses of International 
Watercourses (UN 1997) is such a framework treaty with many champions (Salman 2007, Rieu-Clarke 2011); however, it has, after 15 years, obtained only 29 of the necessary 35 ratifications. Its inadequacies can be shown by comparing it to the International Law Association's (2004) Berlin Rules on Water Resources. The UN Watercourses Convention addresses only transboundary issues and says rather little about concerns other than water sharing. However, if the UN Watercourses Convention were to enter into force, there is nothing stopping the parties from developing it further through amendments. Some nongovernmental organizations (NGOs) are pushing for this route, and there are expectations, because of the NGO promotional activity, that the UN Watercourses Convention may enter into force in the near future.

A second alternative would be to set up an Intergovernmental Negotiating Committee under the auspices of the UN General Assembly to negotiate a more comprehensive treaty that goes beyond the UN Watercourses Convention to include the more up-to-date ideas from the nonbinding Berlin Rules (Dellapenna and Gupta 2008) and other relevant documents. A third option is to find ways of expanding the scope and membership of existing European instruments. The European states have crafted two comprehensive framework instruments: the Helsinki Convention on the Protection and Use of Transboundary Watercourses and International Lakes (UNECE 1992) and the European Union's Water Framework Directive (EU 2000). The Helsinki Convention has a permanent secretariat, a meeting of the parties to keep the convention up-to-date, provisions for continuing research, and options to negotiate new protocols, all lacking in the UN Watercourses Convention. The Helsinki Convention is now open to states outside the United Nations Economic Commission for Europe (UNECE) region who wish to accede to it. Potential amendments and protocols could take on board ideas of equitable sharing from the UN Convention, ideas on hydrologic and administrative issues from the EUs Water Framework Directive, and ideas on conjunctive and ecological management from the Berlin Rules.

However, national governments seem unwilling to commit to such a broad-reaching alteration of global water governance, given their reluctance thus far to ratify the less far-reaching UN Convention. More severe water futures, however, may demand more robust global water governance responses. To prepare for certain foreseeable futures, thinking about very different options should not be neglected completely (Young 2010). The unwillingness to agree to more binding agreements on water rests on the naïve assumption that the water challenges to come can be managed effectively without strong regulatory governance. In fact, today's reluctance to enter into any kind of regulatory framework may generate the need for harsh regulatory measures tomorrow to cope with an aggravated water crisis as the result of present insufficient action.
In terms of the IPCC criteria, a water framework treaty does provide a legal framework, but one that might prematurely rigidify possible responses to the need for linear or, especially, nonlinear change in water management. The ability to adapt to changes in water availability, use, and management could be built into the system, as in the Climate Convention of 1992, if there are mechanisms such as a secretariat, a council of the parties with decision-making authority, and a financial mechanism to generate resources.

\section{A single global water organization}

Because some water problems are global (see other articles, this special feature), it may be appropriate to consider the creation of a single water organization to address the full breadth and depth of at least some water problems. To do so would require the delineation of its functions and of the possible trade-offs that would be necessary to establish it, and would require overcoming the gap between such an arrangement and current global water governance.

Although institutions and organizations are separated for analytical purposes, institutional dimensions research also argues that an organization must be created to ensure actions in accordance with the "rules of the game" of a given institutional arrangement (Young 2008). Thus far, UN-Water and its members provide some intellectual leadership on global water problems, but an organization that has a strong regulatory component and procedural capacity would require much more than marginal tinkering with the mandate of UNWater. For the sake of argument, a UN water organization could be set up, or an existing UN organization could be empowered to steer water governance within the UN system. Such steering would not just be top-down, but would have to take into account the multilevel as well as cross-sectoral nature of water, simultaneously addressing access to water and sanitation and sustainable water resource management. It thus would need to build upon the contributions of different issuespecific bodies and to relate to social networks, while minimizing some of the existing challenges of the bureaucratic system.

If we refer yet again to the IPCC criteria, we see that a global water governance organization, if well designed, could achieve most or all of the goals set for a successful water management institution, yet it is the least politically feasible. Engaging the necessary players in recognizing the nature of the problem and devising the necessary practices will involve time-consuming politics (Young 2008). All of this, proceeding by steps that could be the other institutional arrangements we have considered, will take time, perhaps too much time to respond to the impending crisis in global water governance.

\section{TRANSITIONS TO BETTER GOVERNANCE}

We have argued that there are four distinct potential governance options; that two of the four are politically more 
feasible and cheaper, but that their limited mandates and resources may make them unsuitable for dealing with the serious nature of anticipated global water problems. The other two options, moving toward a global water law and establishing a legitimate, authoritative, independent UN water organization, call even more for discussion of how such a transition might be accomplished and what bottlenecks might stand in the way of such possibilities.

An examination of existing governance transitions at lower levels shows that there are four factors affecting such transitions that might also inform transitions that take place at the global level: the role of agents as analyzed through theories of leadership, policy entrepreneurship, social movements, advocacy coalitions, and social networks; the role of institutions as analyzed through theories of bargaining, scale, interplay, and traps; the role of ideas as analyzed through theories of narratives, discourses, and paradigm shifts; and the role of policy windows/tipping points and crises in creating opportunities for new institution building. If the story is that we are likely to face a structural global water crisis, which is supported by sound scientific evidence as well as by societal movements that have been a major force in global water governance for some time, and which will push not just local communities but also our ecosystems beyond different tipping points for different aspects, an incrementally improved institution alone most likely will be at best able to undertake crisis management, but will not be able to take active and preemptive policy measures to counter or even arrest the problem. If this narrative makes sense, it needs to become part of the discourse and of people's meaning-generating processes, and ultimately implemented in water governance processes.

For a narrative to become effective, there must be agents willing to adopt the narrative at all levels of society, through social networks and movements, advocacy coalitions and policy entrepreneurs, and through structural, directional, and instrumental leadership. Then if there is a policy window, it will be possible to create a global water governance arrangement that matches the severity of the problem facing humankind. To be most effective, the resulting structure should allow for influence from social networks and movements, from civil society, and from all stakeholders, and yet should have the legitimacy and credibility to provide an accountable forum that can steer legally binding decision making at the UN and non-UN level.

\section{CONCLUSION}

Those who consider developing governance strategies to respond to the emerging global water crises must first determine what sort of water future they would prefer, i.e., how they would like to ensure that the two overarching principles of global water governance are met: access for all and sustainable water resource management. Current and expected trends such as rising demand or future pressures stemming from global environmental change, including climate change, which will limit the options at hand, will have to be taken into account, too. Then they must determine what mix of global governance options would be most suitable for bringing about the desired outcomes. Finally, they must pursue strategies that have a chance of bringing those options into effect. We argue that if the scientific evidence of cumulative and systemic water problems shows that we are facing a major structural challenge, we must not shy away from considering structural governance options. However unrealistic such options may appear to be to neorealist international relations scholars or to positivist lawyers, however undesirable such options may appear to be to neoliberals, history shows that there have been transformations of governance systems in the past (Dellapenna and Gupta 2009). The challenge here is to use all relevant knowledge to frame a narrative that can appeal to people and to create a movement, mobilize policy entrepreneurs, and generate leaders.

Several global advocacy institutions focusing on water issues already exist that could be recruited to promote this discussion and, eventually, promote the necessary changes. Among these institutions are International Rivers (www.internationalrivers. org) and Green Cross International (http://www.gcint.org). The issue also needs to be addressed at various international conferences, including the World Water Forum series (most recently in Marseilles, March 2012), the Global Environment Facility's Biennial International Water Conferences (most recently in Dubrovnik, October 2011), and the International Water Resources Association's World Water Congresses (most recently in Porto de Galinhas, Brazil, October 2011). The greater the challenges to human survival and thriving in a given water future, the tighter the governance response must be. This statement should not be misunderstood as arguing per se in favor of top-down measures, yet any substantial global steering required to cope with increasing pressures in the future must go beyond the current global water governance system.

Responses to this article can be read online at:

http://www.ecologyandsociety.org/issues/responses. php/5657

\section{Acknowledgments:}

Joseph Dellapenna is a professor of law at Villanova University School of Law in Pennsylvania. Joyeeta Gupta is a professor at the Amsterdam Institute for Social Science Research of the University of Amsterdam, Netherlands. Wenjing Li is an attorney in Beijing, China, and earned an LL. M. in International Water Law at the University of Macau. Falk Schmidt is academic officer of the Executive Office of the Institute for Advanced Sustainability Studies in Potsdam, 
Germany. This paper has emerged through cooperative work partially supported by the Global Water System Project. The authors thank the reviewers for their detailed comments on previous versions of this paper.

\section{LITERATURE CITED}

Barlow, M., and T. Clarke. 2002. Blue gold: the fight to stop the corporate theft of the world's water. New Press, New York, New York, USA.

Baumgartner, T. 2010. UN-Water and its role in global water governance. Thesis. University of Freiburg, Freiburg, Germany.

Baumgartner, T., and C. Pahl-Wostl. UN-Water and its role in global water governance. Ecology and Society 18(3): 3. http://dx.doi.org/10.5751/ES-05564-180303

Biermann, F., and S. Bauer, editors. 2005. A world environment organization. Solution or threat for effective international environmental governance? Ashgate, Aldershot, UK.

Breitmeyer, H., O. Young, and M. Zürn. 2006. Analyzing international environmental regimes: from case studies to database. MIT Press, Cambridge, Massachusetts, USA.

Burchi, S. 2012. A comparative review of contemporary water resources legislation: trends, developments and an agenda for reform. Water International 37(6):613-627. http://dx.doi $\underline{10.1080 / 02508060.2012 .694800}$

Conca, K. 2006. Governing waters: contentious transnational politics and global institution building. MIT Press, Cambridge, Massachusetts, USA.

Dellapenna, J. 1994. Treaties as instruments for managing internationally shared waters: restricted sovereignty vs. community of property. Case Western Reserve Journal of International and Comparative Law 26:27-56.

Dellapenna, J. 2008. Climate disruption, the Washington consensus, and water law reform. Temple Law Review 81:383-432.

Dellapenna, J., and J. Gupta. 2008. Toward global law on water. Global Governance 14(4):437-453.

Dellapenna, J., and J. Gupta, editors. 2009. The evolution of the law and politics of water. Springer SBM, Amsterdam, the Netherlands, and UNESCO, New York, New York, USA. http://dx.doi.org/10.1007/978-1-4020-9867-3

European Union (EU). 2000. Directive 2000/60/EC of the European Parliament and of the Council of 23 October 2000 establishing a framework for Community action in the field of water policy. Official Journal L 327, 22/12/2000 P. 00010073. EU, Brussels, Belgium. [online] URL: http://eur-lex.
europa.eu/LexUriServ/LexUriServ.do?uri=CELEX:32000L0060: EN:HTML

Gleick, P., and J. Lane. 2005. Large international water meetings: time for a reappraisal. Water International 30:410-414. http://dx.doi.org/10.1080/02508060508691883

Griffin, R. 2006. Water resource economics: the analysis of scarcity, policies, and projects. MIT Press, Cambridge, Massachusetts, USA.

Gupta, J. 2006. Environmental multilateralism: under challenge? Pages 289-307 in E. Newman, R. Takur, and J. Tirman, editors. Multilateralism under challenge? Power, international order, and structural change. United Nations University Press, Tokyo, Japan.

Gupta, J. 2008. Global change: analysing scale and scaling in environmental governance. Pages 225-258 in O. R. Young, H. Schroeder, and L. A. King, editors. Institutions and environmental change: principal findings, applications, and research frontiers. MIT Press, Cambridge, Massachusetts.

Hayward, K. 2012. Global scenarios of the future of water. Water 21:12-17.

Hoekstra, A. Y. 2006. The global dimension of water governance: nine reasons for global arrangements in order to cope with local water problems. Value of Water Research Series No. 20, UNESCO-IHE Institute for Water Education, Delft, The Netherlands.

Hoff, H. 2009. Global water resources and their management. Environmental Sustainability 1:141-147. http://dx.doi. org/10.1016/j.cosust.2009.10.001

Intergovernmental Panel on Climate Change (IPCC). 2001. Climate change 2001: impacts, adaptation and vulnerability. J. J. McCarthy, O. F. Canziani, N. A. Leary, D. J. Dokken, and K. S. White, editors. Contribution of Working Group II to the Third Assessment Report of the Intergovernmental Panel on Climate Change. Cambridge University Press, Cambridge, UK.

Intergovernmental Panel on Climate Change (IPCC). 2007. Climate change 2007: impacts, adaptation and vulnerability. M. L. Parry, O. F. Canziani, J. P. Palutikof, P. J. van der Linden, and C. E. Hanson, editors. Contribution of Working Group II to the Fourth Assessment Report of the Intergovernmental Panel on Climate Change. Cambridge University Press, Cambridge, UK.

International Law Association (ILA). 2004. The Berlin rules on water resources. Report of the Seventy-First Meeting of the International Law Association 335-84. International Law Association, London, UK.

Kämäri, J., J. Alcamo, I. Bärlund, H. Duel, F. Farquharson, M. Flörke, M. Fry, H. Houghton-Carr, P. Kabat, M. Kaljonen, 
K. Kok, K. S. Meijer, S. Rekolainen, J. Sendzimir, R. Varjopuro, and N. Villars. 2008. Envisioning the future of water in Europe: the SCENES project. E-WAter 1-28. [online] URL: http://nora.nerc.ac.uk/9264/1/DIA1-3_EWA_Kamari. pdf

Klijn, A-M., J. Gupta, and A. Nijboer. 2009. Privatizing environmental resources: the need for supervision of clean development mechanism contracts? Review of European Comparative and International Environmental Law 18 (2):172-184. http://dx.doi.org/10.1111/j.1467-9388.2009.00639. $\underline{\mathrm{X}}$

Loucks, D. 2000. Sustainable water resources management. Water International 25(1):3-10. http://dx.doi.org/10.1080/02$\underline{508060008686793}$

Millennium Ecosystem Assessment (MEA). 2005. Ecosystems and human well-being. World Resources Institute, Washington, D.C., USA.

Newman E., R. Thakur, and J. Tirman, editors. 2006. Multilateralism under challenge? Power, international order, and structural change. United Nations University Press, Tokyo, Japan.

Pahl-Wostl, C., J. Gupta, and D. Petry. 2008. Governance and the global water system: a theoretical exploration. Global Governance 14(4):419-435.

Pulver, S. and S. VanDeveer. 2009. "Thinking about tomorrows" scenarios, global environmental politics, and social science scholarship. Global Environmental Politics 9 (2):1-13. [online] URL: http://muse.jhu.edu/journals/gep/ summary/v009/9.2.pulver.html

Rana, S., and L. Kelly. 2004. The global water partnershipaddressing challenges of globalization: an independent evaluation of the World Bank's approach to global programs. World Bank, Washington, D.C., USA.

Rieu-Clarke, A. 2011. The UN watercourses convention: regional and basin perspectives. Presentation at 14th International Water Resources Association (IWRA) World Water Congress, September 25-29, 2011, Porto de Galinhas, Brazil. [online] URL: http://es.slideshare.net/jmccaffery57/ the-un-watercourses-convention-regional-and-basin-perspectives

Rockström, J., W. Steffen, K. Noone, Å. Persson, F. S. Chapin III, E. F. Lambin, T. M. Lenton, M. Scheffer, C. Folke, H. J. Schellnhuber, B. Nykvist, C. A. de Wit, T. Hughes, S. van der Leeuw, H. Rodhe, S. Sörlin, P. K. Snyder, R. Costanza, U. Svedin, M. Falkenmark, L. Karlberg, R. W. Corell, V. J. Fabry, J. Hansen, B. Walker, D. Liverman, K. Richardson, P. Crutzen, and J. A. Foley. 2009. A safe operating space for humanity. Nature 461:472-475. http://dx.doi.org/10.1038/461472a
Rothfeder, J. 2001. Every drop for sale: our desperate battle over water in a world about to run out. Tarcher/Penguin Books, New York, New York, USA.

Salman, S. 2007. The Helsinki Rules, the UN Watercourses Convention and the Berlin Rules: perspectives on international water law. International Journal of Water Resources Development 23(4):625-640. http://dx.doi.org/10.1080/0790$\underline{0620701488562}$

Schubert, S. 2010. Do the UN coordination bodies fulfil their coordination function? A case study of UN-Water, UN-Energy and UN EMG. Thesis. Hamburg, Germany.

Schubert, S., and J. Gupta. 2013. Comparing global coordination mechanisms on energy, environment, and water. Ecology and Society 18(2): 22. http://dx.doi.org/10.5751/ ES-05440-180222

Solanes, M., and A. Jouravlev. 2006. Water governance for development and sustainability. United Nations, Santiago, Chile.

Tecco, N. 2008. Financially sustainable investments in developing countries water sectors: what conditions could promote private sector involvement? International Environmental Agreements: Politics, Law and Economics 8(2):129-142.

United Nations. 1997. Convention on the Law of NonNavigational Uses of International Watercourses. UNGA A/ Res/51/229, adopted 21 May 1997. UN, New York, New York, USA. [online] URL: http://untreaty.un.org/cod/avl/ha/clnuiw/ clnuiw.html

United Nations. 2000. United Nations Millennium Declaration. UNGA A/Res/55/2, adopted 18 September 2000. UN, New York, New York, USA. [online] URL: www.un. org/millennium/declaration/ares552e.pdf

United Nations. 2010. The Human Right to Water and Sanitation. UNGA A/Res/64/292, adopted 28 July 2010. UN, New York, New York, USA. [online] URL: http://www.un. org/ga/search/view doc.asp?symbol=A/RES/64/292

United Nations Conference on Sustainable Development (UNCSD). 2012. Report of the United Nations Conference on Sustainable Development. A/CONF.216/16, June 20-22, 2012, Rio de Janeiro, Brazil. UN, New York, New York, USA. [online] URL: http://www.uncsd2012.org/content/ documents/814UNCSD\%20REPORT\%20final\%20revs.pdf

United Nations Economic Commission for Europe (UNECE). 1992. Convention on the Protection and Use of Transboundary Watercourses and International Lakes, adopted 17 March 1992. UNECE, Helsinki, Finland. [online] URL: http://www. unece.org/fileadmin/DAM/env/water/pdf/watercon.pdf. 
United Nations Educational, Scientific and Cultural Organization (UNESCO). 2006. Water, a shared responsibility: The United Nations World Water Development Report 2 (WWDR2). UNESCO Publishing/Berghahn Books, Oxford, UK, and Brooklyn, New York, USA.

United Nations Educational, Scientific and Cultural Organization (UNESCO). 2009. Water in a changing world: The United Nations World Water Development Report 3 (WWDR 3). UNESCO Publishing / Earthscan. [online] URL: http://www.unesco.org/new/en/natural-sciences/environment/ water/wwap/wwdr/wwdr3-2009/downloads-wwdr3/

United Nations Environment Programme (UNEP). 2007. Global Environment Outlook 4 (GEO-4): environment for development. United Nations Environment Programme, Nairobi, Kenya.

United Nations Secretary-General's Advisory Board on Water and Sanitation (UNSGAB). 2006. Hashimoto Action Plan. United Nations, New York, New York, USA. [online] URL: http://www.unsgab.org/content/documents/HAP en.pdf

United Nations Secretary-General's Advisory Board on Water and Sanitation (UNSGAB). 2010. Hashimoto Action Plan II. United Nations, New York, New York, USA. [online] URL: http://www.unsgab.org/content/documents/HAP-II_en.pdf

UN-Water. 2010. A guide to UN-Water. United Nations, New York, New York, USA.

van Putten, M. 2008. Policing the banks: accountability mechanisms for the financial sector. McGill-Queen's University Press, Montreal, Quebec, Canada.

Vörösmarty, C. J., P. B. McIntyre, M. O. Gessner, D. Dudgeon, A. Prusevich, P. Green, S. Glidden, S. E. Bunn, C. A. Sullivan, C. R. Liermann, and P. M. Davies. 2010. Global threats to human water security and river biodiversity. Nature 467:555-561. http://dx.doi.org/10.1038/nature09440

Young, O. 2008. Building regimes for socioecological systems, institutional diagnostics. Pages 115-143 in O. R. Young, H. Schroeder, and L. A. King, editors. Institutions and environmental change: principal findings, applications, and research frontiers. MIT Press, Cambridge, Massachusetts, USA.

Young, O. 2010. Institutional dynamics: emergent patterns in international environmental governance. MIT Press, Cambridge, Massachusetts, USA. 